\title{
Prototype Automation of Air Conditioning Treatment in the Grinding Area AK Based on IoT
}

\author{
Johan Eko Prasetyo, Jamaaluddin Jamaaluddin*, \\ Department of Electrical Engineering, Faculty of Science and Technology, \\ Universitas Muhammadiyah Sidoarjo, East Java, Indonesia \\ *Corresponding author, e-mail: jamaaluddin@umsida.ac.id
}

\begin{abstract}
A good work environment will affect the level of productivity of workers in a company. The operation of the refrigeration machine in the cocoa powder grinding area is very important in production. The indicators for the operation of the cooling machine are dust density, ambient temperature and wind speed. With control on the indicator will increase efficiency. In this study, the indicator is controlled with a GP2Y1010AUFOF dust sensor, a DHT22 temperature sensor, a DS18B20 sensor, and a wind speed sensor as sensor inputs. Furthermore, the sensor will be processed by the Node M CU ESP826 module. System output will be displayed on LED and android. The results of this study indicate the accuracy of the dust sensor is $96.12 \%$, the DHT22 temperature sensor is $99.80 \%$, the DS18B20 temperature sensor is $99.57 \%$ and the speed sensor is $95.89 \%$. In this prototype, we can monitor the temperature of the air velocity of dust particles in the engine and the temperature of the engine cooler together and closely monitored.
\end{abstract}

Keywords: DHT22 sensor; dust sensor GP2Y1010AUFOF; DS18B20 sensor; Velocity sensor Internet of Things.

\section{Introduction}

Air conditioning systems have become a major requirement in boosting worker productivity. The performance and productivity of employees in the industrial world can be affected by good room temperature. Employees whose work environment is arranged according to their needs will affect employee morale. So that the production process will run more optimally [1]. The use of artificial intelligence accompanies technological developments, for example the application of Fuzzy type 2 and algorithms will make the system more intelligent, can increase precision in operations and save electricity[2][3].

During the production process, air is circulated regularly using a blower motor. The performance of the cooling engine is affected by the blower, cooler and air filter. The air filter must be cleaned every 2 shifts to keep the room temperature stable. However, in some cases, the operator or maintenance technician in charge of cleaning and replacing the filter is often late in the process of the existing air filter. So that the temperature of the production room becomes hot. As for some cases, the filtering and evaporator purge processes were carried out for too long and had to stop the production process.

Making this tool using GP2Y1010AUFOF, dust sensor, temperature sensor, DHT22 sensor, DS18B20 Sensor and wind speed sensor as input[4][5]. Blynk application and $L C D$ as on-device monitor. It can also be controlled via a smartphone so that technicians can easily monitor air-conditioned maintenance. In the blynk display on the smartphone application, the monitoring of the five sensors will be displayed. And from this application the user can set the machine time to run either automatically or manually. In the application there can also be an alarm if any parameter exceeds the pre-programmed set[6].

\section{Theoretical Review}

\section{II.1. NodeMCU ESP8266}

The NodeMCU ESP8266 module is a very complex chip. Inside is a processor. This processor serves to transfer data over a wi-fi network. The parameters used in the transfer process are pre-programmed. The NodeMCU ESP8266 module also has memory and access to GPIO (General Purpose Input/Output). This allows NodeMCU ESP8266 to be used to create internet-based devices. The use of the NodeMCU 
ESP8266 module as a wi-fi module can reduce costs because the value is more affordable and the data transmission speed is $80 \mathrm{MHz}$ [7].

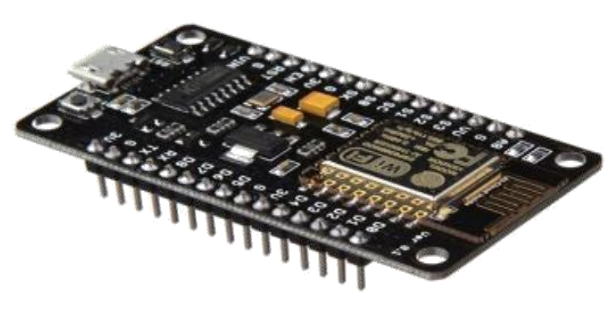

Figure 1. NodeMCU ESP8266

\section{II.2. Dust Sensor GP2Y1010AUFOF}

The GP2Y1010AUF0F dust sensor is a sharp sensor that uses infrared as a sensor reading process. This dust sensor is often used to detect fine particles such as dust and cigarette smoke. Because it is very effective and is often used for both air cleaning systems and indoor air monitoring. The sensor operates at a maximum input voltage of 7 volt, operating temperature between $10^{\circ}$ and $65^{\circ} \mathrm{C}[4]$.

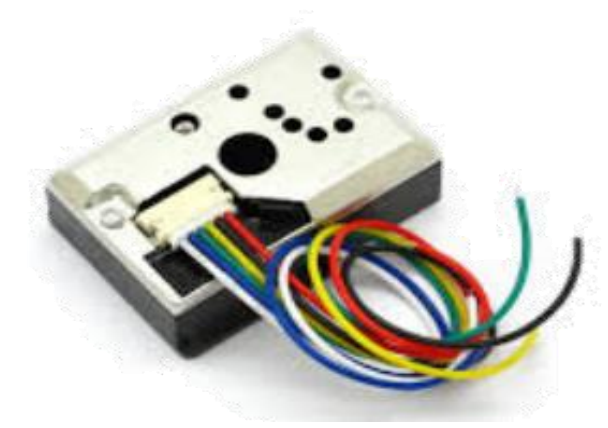

Figure 2. Dust Sensor

\section{II.3. Temperature sensor DHT22}

The DHT22 sensor is a sensor used to detect temperature and humidity. The DHT22 sensor works with a voltage input of 3.3 volt to 6 volt. Then this sensor will function to display thermal data, which indicates an alarm on the equipment that can be observed and will be displayed on the LCD screen[8].

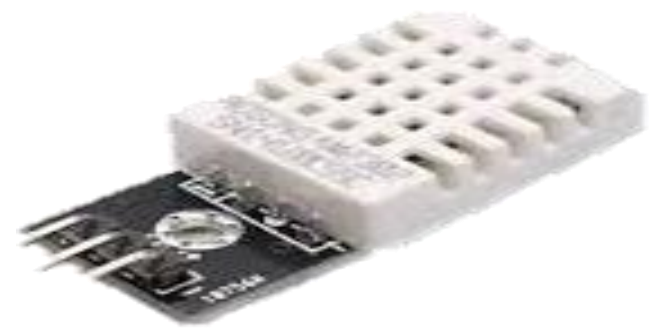

Figure 3. DHT22 Sensor

Copyright $\odot 2021$ Journal of Electrical Technology UMY

\section{II.4. Velocity Sensor}

The wind speed sensor is a sensor that can detect the flow of air passing through it. This sensor has a principle like an anemometer. The sensor will send wind speed data. The sensor works on a voltage of 5 volt. Inside the sensor device, there is an LM393 sensor. The sensor will work by counting the number of revolutions per minute[5].

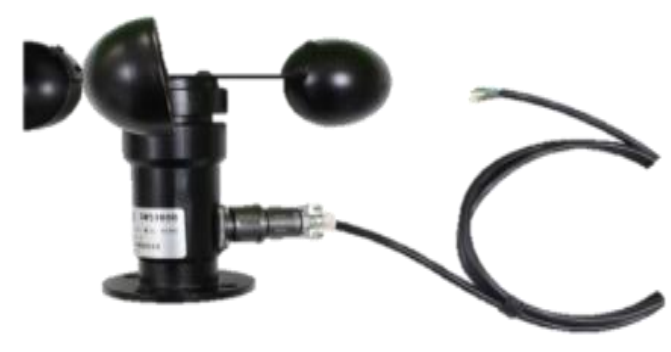

Figure 4. Velocity Sensor

\section{II.5. DS18B20 Sensor}

The $D S 18 B 20$ sensor is a temperature sensor that works with a single input cable. This sensor works with an input voltage of 3 volt to 5.5 volt. This sensor has an accuracy of $\pm 0.5^{\circ} \mathrm{C}$ with readings between $-10^{\circ} \mathrm{C}$ to $85^{\circ} \mathrm{C}$ [7][9][10].

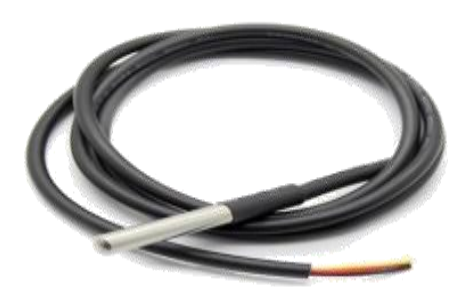

Figure 5. DS18B20 Sensor

\section{II.6. Blynk Aplication}

The blynk is one of several free apps that can be downloaded inside smartphones that have the function of controlling microcontrollers and the like via the Internet. The blynk application was created to apply the Internet system of things. It is used to control hardware remotely and to display some sensor data and so forth. The blynk application can be used to store data, visuals and others according to the user's application [11][12][13][14]. 


\section{Research Methodology}

\section{III.1. Block Diagram System}

The GP2Y1010AUFOF dust sensor, DS18B20 temperature sensor, DHT 22 temperature sensor and flow rate sensor will be processed by the NodeMCU ESP8266 microcontroller. In this system, the NodeMCU ESP8266 will process input from the dust sensor, air flow sensor and temperature sensor which are then displayed on a $20 \times 4 L C D$.

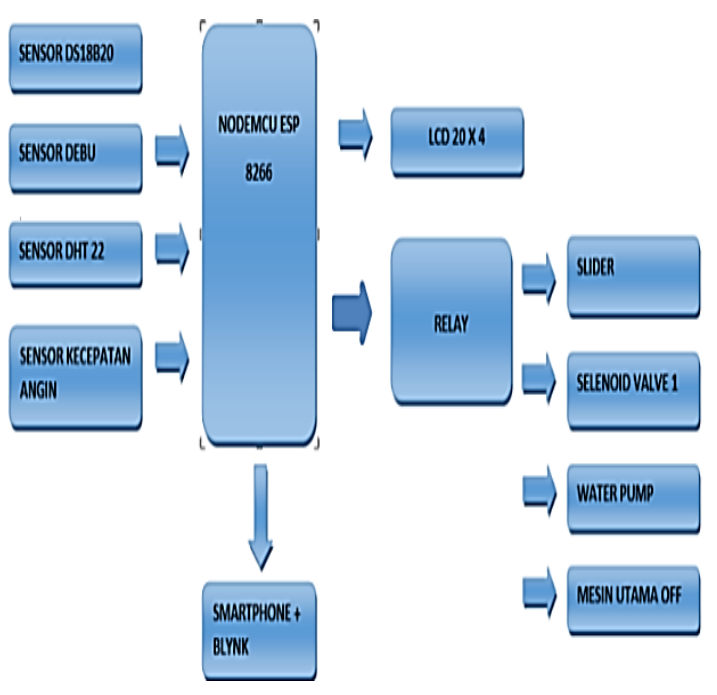

Figure 6. Block Diagram System

The step down module functions to change the input voltage from the power supply to the NodeMCU ESP8266 module. The dc motor will work to move the slider and sprayer nozzle, then spray water into the evaporator automatically as Figure 6 . In the current system there are several tools to facilitate machine maintenance. The way it works is using a slider that works automatically while spraying water. This water spray cleans the evaporator from dirt.

In the system being developed at this time there is also a blynk application. Which is an application that will display several features such as manual and automatic modes. Then on the device that is now made, it can also display monitoring sensors. In the current system, there is an alarm that will sound if the parameter exceeds the set from the programmed set.

\section{III.2. Flowchart Application}

In Figure 7, the system flowchart is described as follows:

1. Starting, the first step involved is to provide voltage belly-up to the device.

Copyright $(2021$ Journal of Electrical Technology UMY
2. Blynk connection check applications, in this process tools are linked with the Internet to find out if the tool is online and also to find out if the blynk application is connected to the tool.

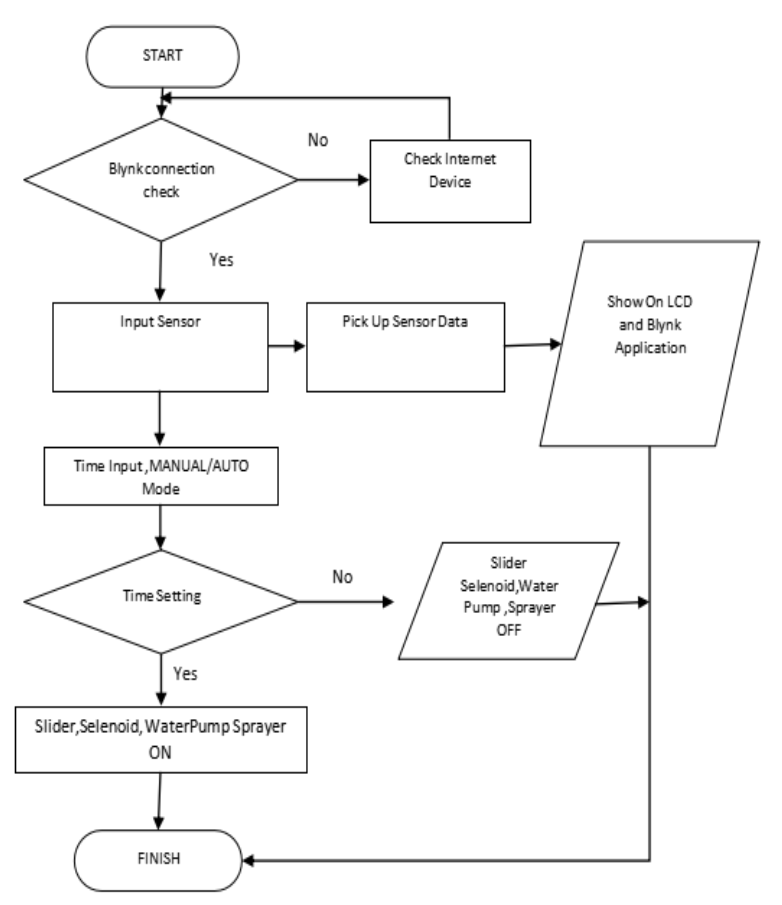

Figure 7. Flowchart Application

3. Check Internet devices, this process shows a process in which the blynk is not connected and the device goes back to searching for an Internet connection or wi-fi.

4. NodeMCU ESP8266 will read intake from room temperature sensor, humidity sensor, wind speed, dust particles and motor temperature.

5. The process of taking data from the sensor is done in real time. Room temperature is taken during the production process. The humidity sensor works to retrieve humidity data in the production room. Wind speed is obtained when the cooling machine is running. At that time the blower will circulate air, and the sensor reads how much air flow.

6. The working dust sensor will take dust samples in the production area. The temperature sensor works by taking the temperature when the engine coolant is operating.

7. The output of the microprocessor is displayed on the $L C D$ on the system and on the blynk on Android. All sensor outputs are displayed on the $L C D$ and blink.

8. For time settings can also be done on the system. Likewise, manual auto settings can be

Journal of Electrical Technology UMY, Vol. 5, No. 2 
done. This provides convenience at the time of research or operations. The process on the system is done based on the time that is set.

9. The last stage is to unify the indicators of dust, room temperature, motor temperature, humidity and air flow on the $L E D$ and android by using the blynk application.

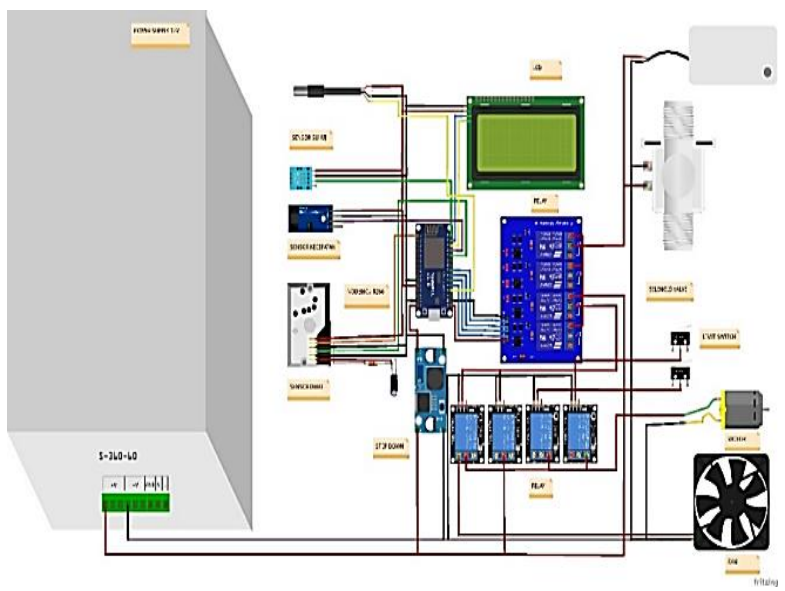

Figure 8. Wiring Design

Figure 8 is a picture of electricity line and tool placement position.

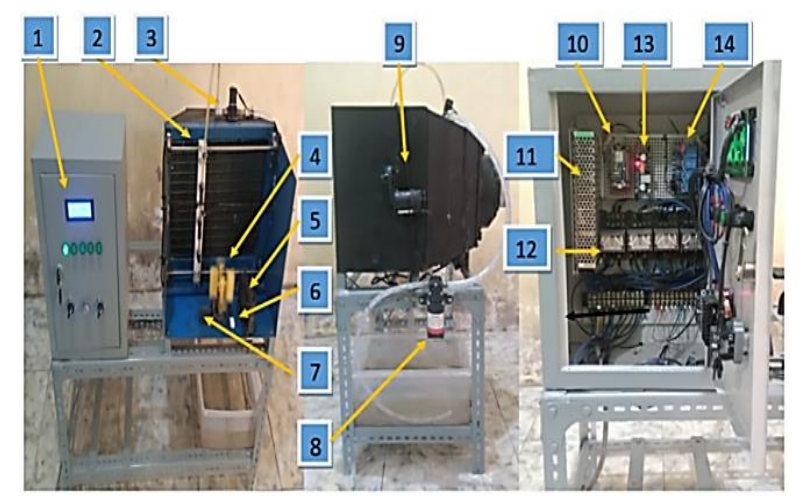

Figure 9. Mechanical Design

Figure 9 is a mechanical design. The system is placed on a panel with a height of $40 \mathrm{~cm}$, a length of $30 \mathrm{~cm}$ and a width of $20 \mathrm{~cm}$. The picture shows the placeholder and sprayer designs for the evaporator cleaning process. As for the power supply, it is placed inside the panel. The devices include: a power supply circuit, relay, $L C D$, voltmeter and potentiometer. Sensor devices in the system are also connected to this panel.

in Figure 9 there is a series of components as follows:

1. LCD $20 \times 4$

2. Slider + Sprayer Nozzle
3. Selenoid Valve 12VDC

4. Sensor Angin

5. Fan 12 VDC

6. Sensor DHT 22

7. Sensor Debu GP2Y1010AU0F

8. Water Pump

9. Sensor DS18B20

10. NodeMCU ESP8266

11. Power Supply

12. Relay LY4 12VDC

13. Modul StepDown

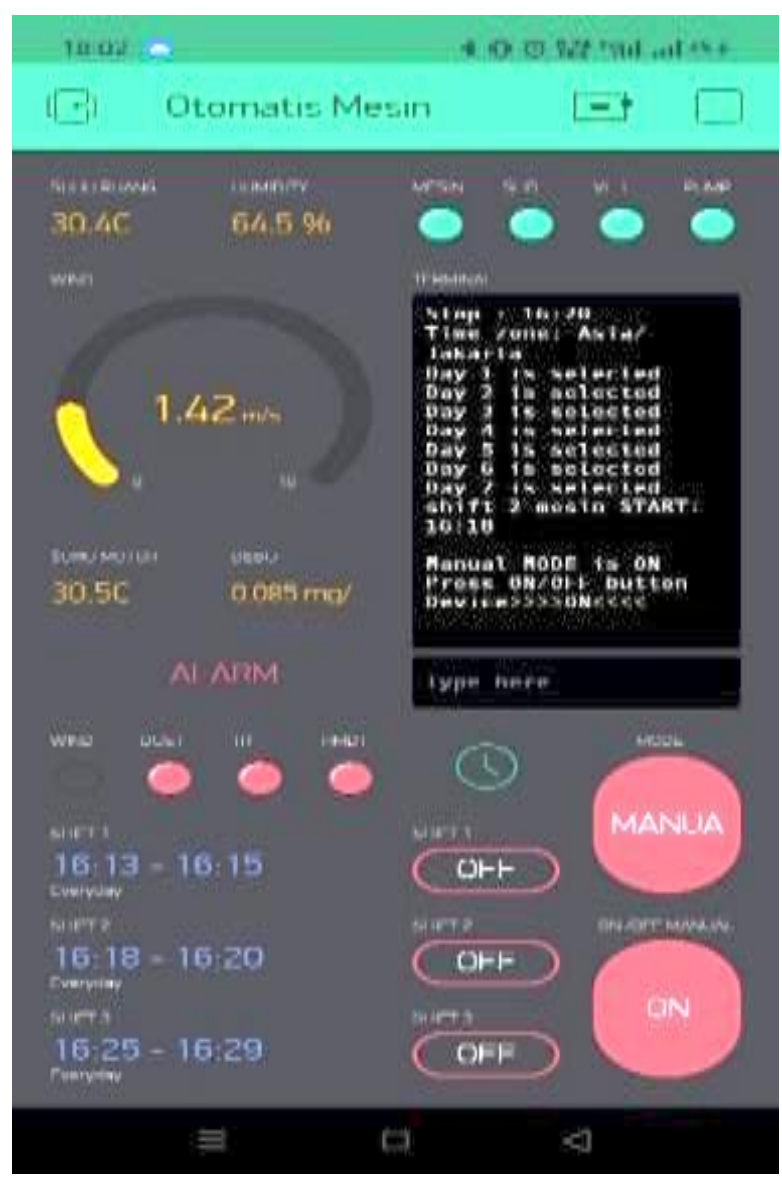

Figure 10. Blynk Application Display

In Figure 10 is an android display of engineering treatment. There are five parameters displayed, namely room temperature, room humidity, wind speed, dust particles and motor temperature. This device also displays manual and automatic settings for easy use of the tool. In the automatic setting the user can set the time when the machine will start and shut down. In this application, the sensor value is displayed on the $L E D$. 
TABLE I

NODEMCU PoRT UsAge

\begin{tabular}{lcl}
\hline \hline No & NodeMCU Port & \multicolumn{1}{c}{ Usage } \\
\hline 1 & D0 & Relay Machine \\
2 & D1 & SCL LCD \\
3 & D2 & SDA LCD \\
4 & D3 & Dust Sensor \\
5 & D4 & DS18B20 Sensor \\
6 & D5 & Velocity Sensor \\
7 & D6 & Relay Slider \\
8 & D7 & Relay Selenoid Valve \\
9 & D8 & Relay Water Pump \\
10 & D9 & DHT22 Sensor \\
11 & A0 & Dust Sensor \\
\hline \hline
\end{tabular}

\section{Results and Discussion}

In the results and discussion section, it will be explained about the testing of each sensor. It aims to determine whether the sensor is working properly or not. This test is done by comparing the sensor on the system with the actual measuring instrument. These comparison tools include thermometers, hygrometers, anemometers, and multimeters. So that the accuracy of each sensor will be known[15].

TABLE II

Testing TEMPERATURE SENSOR DHT22

\begin{tabular}{|c|c|c|c|}
\hline No. & - $\quad$ Parameters & Result & Accuracy $(\%)$ \\
\hline 1 & Thermometer & $33,06^{\circ} \mathrm{C}$ & \multirow[b]{2}{*}{$99,57 \%$} \\
\hline 2 & DS18B20 Sens & $\mathrm{r} 33,30^{\circ} \mathrm{C}$ & \\
\hline
\end{tabular}

In table 2, it can be seen that the experimental results show the accuracy value shows a result of $99.87 \%$.

TABLE III

Testing Humidity SENSOR DHT22

\begin{tabular}{|c|c|c|}
\hline No & Parameters & $\begin{array}{c}\text { Accuracy } \\
(\%) \\
\end{array}$ \\
\hline \multicolumn{3}{|c|}{$\begin{array}{l}1 \text { Higrometer UNI-T } 333 \quad 61,20 \% \\
\end{array}$} \\
\hline \multicolumn{3}{|c|}{2 Humidity Sensor DHT 22 61,08\% } \\
\hline
\end{tabular}

In table 3 the sensor test values show an accuracy of $99.80 \%$. So it can be concluded that the DHT22 sensor works well.
TABLE IV

TESTING DUST SENSOR GPAY1010AU0F

\begin{tabular}{lcc}
\hline \hline No. & Parameters & Result Accuracy (\%) \\
\hline 1 & Multimeter FLUKE 101 & $1,153 \mathrm{~V}$ \\
2 & Dust Sensor GPAY1010AUOF $1,108 \mathrm{~V}$ & $96,12 \%$ \\
\hline
\end{tabular}

Table 4 shows the results of the sensor testing accuracy of $96.12 \%$. So it can be concluded that the GP2Y1010AU0F dust sensor works well.

TABLE V

TESTING VELOCITY SENSOR

\begin{tabular}{|c|c|c|c|}
\hline No & Parameters & Result & $\begin{array}{c}\text { Accuracy } \\
(\%)\end{array}$ \\
\hline 1 & Anemometer UNI-T 363 & $1,64 \mathrm{~m} / \mathrm{s}$ & \multirow{2}{*}{$95,89 \%$} \\
\hline 2 & Velocity Sensor & $1,71 \mathrm{~m} / \mathrm{s}$ & \\
\hline
\end{tabular}

At the table 5 value sensor testing shows an accuracy of $95.89 \%$. So it can be concluded that wind speed sensors can work well to monitor wind speeds in the machine.

TABLE VI

TESTING DS18B20 SENSOR

\begin{tabular}{|c|c|c|c|}
\hline No. & Parameters & Result & Accuracy $(\%)$ \\
\hline 1 & Thermometer & $33,06^{\circ} \mathrm{C}$ & \multirow[b]{2}{*}{$99,57 \%$} \\
\hline 2 & DS18B20 Sens & $\mathrm{r} 33,30^{\circ} \mathrm{C}$ & \\
\hline
\end{tabular}

In table 6, it can be seen that the accuracy sensor test value is $99.57 \%$. So it was concluded that the DS18B20 temperature sensor worked well.

TABLE VII

TESTING INTERNET CONECTIONS

\begin{tabular}{|c|c|c|c|}
\hline \multicolumn{2}{|c|}{$\begin{array}{r}\text { Smartphone type Distance } \\
(\mathrm{km})\end{array}$} & Location & $\begin{array}{c}\text { Accuracy } \\
(\%)\end{array}$ \\
\hline Realme 3 & $0,45 \mathrm{~km}$ & $\mathrm{AK}$ & 100 \\
\hline Samsung Note & $2,9 \mathrm{~km}$ & Perumahan Puri Indah & 100 \\
\hline Realme C11 & $4,3 \mathrm{~km}$ & Lippo Plaza Sidoarjo & 100 \\
\hline Realme 3 & $7,4 \mathrm{~km}$ & Kampus 2 UMSIDA & 100 \\
\hline Poco X3 & $19 \mathrm{~km}$ & $\begin{array}{l}\text { Islamic Center } \\
\text { Surabaya }\end{array}$ & 100 \\
\hline
\end{tabular}

At table 7 shows the results of testing the operating distance of the tool to know the performance of the instrument. Testing results show $100 \%$ accuracy and can be deduced that the device works properly.

Journal of Electrical Technology UMY, Vol. 5, No. 2 
TABLE VIII

Testing BLynk Display

\begin{tabular}{ccccc}
\hline \hline Testing & $\begin{array}{c}\text { Blynk } \\
(\mathrm{m} / \mathrm{s})\end{array}$ & $\begin{array}{c}\text { LCD } \\
(\mathrm{m} / \mathrm{s})\end{array}$ & $\begin{array}{c}\text { Deviation Accuracy\% } \\
(\mathrm{m} / \mathrm{s})\end{array}$ & \\
\hline 1 & 0,97 & 0,97 & 0 & 100 \\
2 & 1,31 & 1,31 & 0 & 100 \\
3 & 1,33 & 1,33 & 0 & 100 \\
4 & 1,56 & 1,56 & 0 & 100 \\
5 & 1,67 & 1,67 & 0 & 100 \\
\hline \hline
\end{tabular}

At the table 8 test values shows $100 \%$ accuracy. So it seems to suggest that the instrument works properly

TABLE IX

TESTING RELAY

\begin{tabular}{lcccc}
\hline \hline \multicolumn{1}{c}{ Testing } & Blynk & Kits & $\begin{array}{c}\text { Status } \\
\text { accuracy } \\
(\%)\end{array}$ \\
\hline Re1ay 4 ON & ON & ON & ON & 100 \\
Relay 1 dan 4 ON & ON & ON & ON & 100 \\
Relay 1,2 dan 4 ON & ON & ON & ON & 100 \\
Relay 1,2,3,4 ON & ON & ON & ON & 100 \\
Relay 1,2,3,4 OFF & OFF & OFF & OFF & 100 \\
\hline \hline
\end{tabular}

Table 9 shows the results of the relay testing on the tools in which the testing results show that the tools can work according to the command run on the blynk application.

\section{Conclusion}

Automatic $A C$ maintenance system in $\mathrm{AK}$ have been doing well. The test results use four kinds of sensors, namely: the DHT22 temperature sensor can read the room temperature with an accuracy of $99.87 \%$, the DHT22 can also read the humidity in the room with an accuracy of $99.80 \%$. For GP2Y1OFAFO Dust sensor can read dust particles with an accuracy of $96.12 \%$ speed sensor and measure wind speed can be read with an accuracy of $95.89 \%$. DS18B20 sensor for temperature monitor, can read temperature with $99.57 \%$ accuracy. The use of these 4 sensors is quite optimal. Among other things, because the socket on the NodeMCU ESP8266 is not enough to accept additional sensor input. In the future, sensors can be added to control the amplifier in the machine. To facilitate this, in the future ESP32 can be used.

\section{References}

[1] I. Pratiwi, "Pengaruh Pencahayaan, Kebisingan Dan Temperatur Terhadap Performansi Kerja,"
Nas. Conf. Appl. Ergon., pp. 1-7, 2013.

Jamaaluddin, I. Robandi, I. Anshory, Mahfudz, and R. Rahim, "Application of interval type-2 fuzzy inference system and big bang big crunch algorithm in short term load forecasting new year holiday," J. Adv. Res. Dyn. Control Syst., 2020.

[3] Jamaaluddin, I. Robandi, and I. Anshory, "A very short-term load forecasting in time of peak loads using interval type-2 fuzzy inference system: A case study on java bali electrical system," J. Eng. Sci. Technol., vol. 14, no. 1, pp. 464-478, 2019.

[4] W. Febri Aji, "Rancang bangun sistem pendeteksi debu berbasis arduino," vol. 6, no. 2, pp. 31-41, 2017.

[5] FANNIDA SHEILLA HARAHAP, "Pengukuran Dan Pengujian Kecepatan Angin Dengan Menggunakan Sensor Anemometer Berbasis Arduino Uno R3,” pp. 44-48, 2018.

[6] F. Muliawati and A. Seftiana, "Prototipe Sistem Otomatis Pengukuran Densitas Debu, Kelembaban Udara, Dan Suhu Ruang Berbasis Mikrokontroler Atmega 32 Untuk Sterilisasi Udara Pada Ruang Perakitan Lensa Kamera," Juteks, 2016.

[7] U. Syafiqoh, S. Sunardi, and A. Yudhana, "Pengembangan Wireless Sensor Network Berbasis Internet of Things untuk Sistem Pemantauan Kualitas Air dan Tanah Pertanian," J. Inform. J. Pengemb. IT, 2018.

[8] D. Iswahyudi, I. Anshory, and J. Jamaaluddin, "Rancang Bangun Alat Pengontrol Kelembaban Udara Pada Budidaya Jamur Menggunakan Arduino Uno Dan Ultrasonik Mist Maker," J. Elektron. List. Telekomun. Komputer, Inform. Sist. Kontrol, vol. 2, no. 1, pp. 28-37, 2020.

[9] I. Abdul Rozaq and N. D. Yulita, UJI KARAKTERISASI SENSOR SUHU DS18B20 WATERPROOF BERBASIS ARDUINO UNO SEBAGAI SALAH SATU PARAMETER KUALITAS AIR. .

[10] S. RAHARJO, "SISTEM OTOMATISASI FOTOSINTESIS BUATAN PADA AQUASCAPE BERBASIS ARDUINO," Apr. 2018.

[11] I. Sulistiyowati, Y. Findawati, S. K. A. Ayubi, J. Jamaaluddin, and M. P. T. Sulistyanto, "Cigarette detection system in closed rooms based on Internet of Thing (IoT)," J. Phys. Conf. Ser., vol. 1402, no. 4, 2019.

[12] J. Jamaaluddin, I. Sulistiyowati, B. W. A. Reynanda, and I. Anshory, "Analysis of Overcurrent Safety in Miniature Circuit Breaker AC (Alternating Current) and DC (Direct Current) in Solar Power Generation Systems," IOP Conf. Ser. Earth Environ. Sci., vol. 819, no. $1,2021$.

[13] A. Solih and J. Jamaaluddin, "Rancang Bangun Pengaman Panel Distribusi Tenaga Listrik Di 
Lippo Plaza Sidoarjo Dari Kebakaran Berbasis Arduino Nano," JEEE-U (Journal Electr. Electron. Eng., 2017.

[14] J. Jamaaluddin, "Sistem Kontrol Pendingin Mobil Ramah Lingkungan Berbasis Android," CYCLOTRON, 2019.

[15] I. ANSHORY, I. ROBANDI, J. Jamaaluddin, A. FUDHOLI, and WIRAWAN, "Transfer function modeling and optimization speed response of bldc motor e-bike using intelligent controller," $J$. Eng. Sci. Technol., vol. 16, no. 1, pp. 305-324, 2021.

\section{Authors' information}

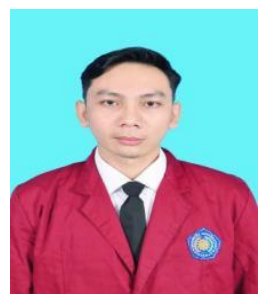

Johan Eko Prasetyo is a student of Electrical Engineering, Department of Electrical Engineering, Faculty of Science and Technology, Universitas Muhammadiyah Sidoarjo.

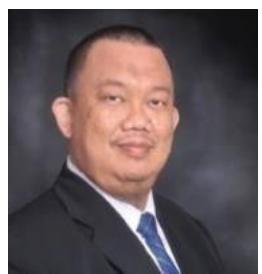

Jamaaluddin Jamaaluddin was born in Surabaya, October 17, 1970, and completed his doctoral education at ITS Surabaya in 2020. The research fields carried out are in the fields of power systems and artificial intelligent. Several scientific journal manuscripts have been published. he is a lecturer in the electrical engineering study program, Muhammadiyah University of Sidoarjo. East of Java Indonesia, became the head of the energy conversion and electric power engineering laboratory. He has an IEEE members and etc. 